\title{
Adopting Modular Construction in the Malaysian Construction Industry
}

\author{
Muhamad Faiz Musa, Mohammad Fadhil Mohammad, \\ Rohana Mahbub, Mohd Reeza Yusof
}

Construction Economics and Procurement Research Group, Centre of Studies for Quantity Surveying, Faculty of Architecture, Planning \& Surveying, Universiti Teknologi MARA (UiTM), 40450 Shah Alam, Selangor, Malaysia

faeezzz@yahoo.com

\begin{abstract}
Prefabrication and offsite construction promotes sustainability in the construction environment and industry that is essential to protect ecosystems, improves air quality, reduces waste, conserves natural resources and improves water quality. This paper discusses a study on adopting modular construction through Industrialised Building System (IBS) approach in the Malaysian construction industry. The sustainability principles in offsite construction and IBS have always maintained a balance between environment and construction, improve human self-respect and encourage economic development.

Keywords: Modular Construction; Industrialised Building System (IBS); Malaysian Construction Industry; Sustainability

eISSN 2514-751X ๔ 2018. The Authors. Published for AMER ABRA cE-Bs by e-International Publishing House, Ltd., UK. This is an open-access article under the CC BY-NC-ND license (http://creativecommons.org/licenses/bync-nd/4.0/). Peer-review under responsibility of AMER (Association of Malaysian Environment-Behaviour Researchers), ABRA (Association of Behavioural Researchers on Asians) and CE-Bs (Centre for EnvironmentBehaviour Studies), Faculty of Architecture, Planning \& Surveying, Universiti Teknologi MARA, Malaysia DOI: https://doi.org/10.21834/aje-bs.v3i10.307
\end{abstract}




\subsection{Introduction}

The construction industry is essential to any nation's growth as it plays an economic role to the nation's Gross Domestic Product (GDP). In addition to the economic importance, the construction industry also accounts for a high political, environmental and social profile, providing a crucial role in providing development and construction, as well as being a vital employer. Even though, Malaysian construction industry contributes around 3\% to the GDP in the year 2010 construction industry, but it is a significant contributor to the multiplier effects to other industries. Therefore, the construction industry is an important economic driver in Malaysia's economic growth. The state of the Malaysian construction industry is not in line with the future development of Malaysia. These are due to the lack of quality, low productivity, non-environment friendly, lack of safety and excessive reliance on unskilled foreign workers (CIDB, 2003).

The Malaysian government introduced IBS Roadmap and Construction Industry Master Plan (CIMP) 2006-2015 to improve and modernise the Malaysian construction industry that has been facing problems and issues. The aim of IBS adoption in Malaysia is to reduce the usage of foreign labour in the construction industry and save the country's loss in foreign exchange (Hamid, 2008). IBS provides the opportunity for the construction industry players to project a new image of the industry to be on par with manufacturing based industries. In addition, the adoption of IBS promises to alleviate every level of the construction industry to a new height and image of professionalism. Furthermore, the adoption of IBS will provide efficient, clean, safe and innovative attributes that will be associated with the Malaysian construction industry. IBS will save valuable time, and it helps to reduce the risk of project delays and possible monetary losses (CIMP, 2007).

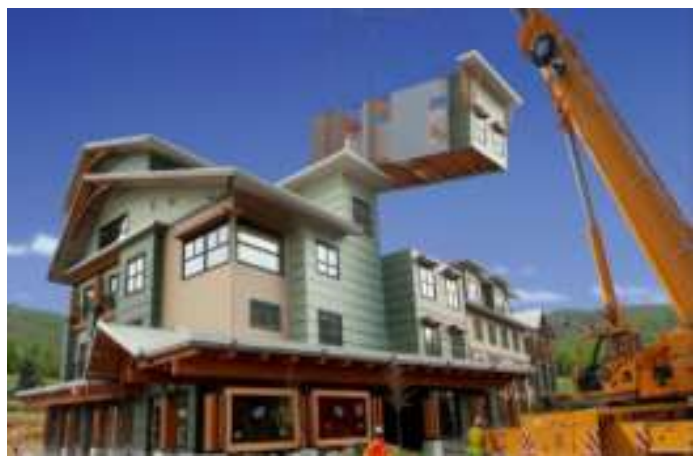

Figure 1: Modular construction

(Source: Modular Building Institute (MBI) Website)

Modular construction can be categorised into Modern Method of Construction (MMC) and offsite construction. Developed countries such as the US, Australia, Japan and UK use modular construction due to its advantages and benefits (Lawson, 2012). Modular 
construction is a construction method that produces a building consist of modular units or modules, mass produce off site in a manufacturing facility. It includes the logistic and assembly aspect of it, done in proper coordination with through planning and integration (Muhamad Faiz Musa, Yusof, Mohammad, \& Mahbub, 2014). Modular construction also produces less wastage, fewer site materials, a neater and cleaner environment, controlled quality because modular construction is produced in a factory. In addition, modular construction provides sustainable design and construction solutions for improved environmental impact (MBI, 2010). By adopting modular construction in the Malaysian construction industry through IBS approach, not only will it lead to a better and improved building, but it will also enhance sustainability.

\subsection{LITERATURE REVIEW}

\begin{tabular}{|c|c|c|c|c|c|c|}
\hline & \multicolumn{5}{|c|}{ Construction Industry Master Plan (CTMP) 2006-2015 } & \\
\hline $\begin{array}{l}\text { Strategic } \\
\text { Thrust } 1\end{array}$ & $\begin{array}{l}\text { Strategic } \\
\text { Thrust } 2\end{array}$ & $\begin{array}{l}\text { Strategic } \\
\text { Thrust } 3\end{array}$ & $\begin{array}{l}\text { Strategic } \\
\text { Thrust } 4\end{array}$ & $\begin{array}{l}\text { Strategic } \\
\text { Thrust } 5\end{array}$ & $\begin{array}{l}\text { Strategic } \\
\text { Thrust } 6\end{array}$ & $\begin{array}{l}\text { Strategic } \\
\text { Thrust } 7\end{array}$ \\
\hline $\begin{array}{l}\text { Integrate the } \\
\text { construction } \\
\text { industry } \\
\text { value chain } \\
\text { to enhance } \\
\text { productivity } \\
\text { and } \\
\text { efficiency }\end{array}$ & $\begin{array}{l}\text { Strengthen } \\
\text { construction } \\
\text { industry } \\
\text { image }\end{array}$ & $\begin{array}{l}\text { Strive for the } \\
\text { highest } \\
\text { standard of } \\
\text { quality. } \\
\text { occupational } \\
\text { safety and } \\
\text { health and } \\
\text { environmental } \\
\text { practices }\end{array}$ & $\begin{array}{l}\text { Develop } \\
\text { human } \\
\text { resource } \\
\text { capabilities } \\
\text { and } \\
\text { capacities in } \\
\text { the } \\
\text { construction } \\
\text { industry }\end{array}$ & $\begin{array}{l}\text { Innovate } \\
\text { through } \\
\text { research and } \\
\text { development } \\
\text { and adopt } \\
\text { new } \\
\text { construction } \\
\text { methods }\end{array}$ & $\begin{array}{l}\text { Leverage on } \\
\text { information } \\
\text { and } \\
\text { communication } \\
\text { technology } \\
\text { in the } \\
\text { construction } \\
\text { industry }\end{array}$ & $\begin{array}{l}\text { Benefit } \\
\text { from } \\
\text { globalisation } \\
\text { including } \\
\text { the export } \\
\text { of } \\
\text { construction } \\
\text { products } \\
\text { and services }\end{array}$ \\
\hline $\begin{array}{l}\text {-Consolidate } \\
\text { the industry } \\
\text {-Standardise } \\
\text { and integrate } \\
\text { administrativ: } \\
\text { practices } \\
\text { and } \\
\text { procedures }\end{array}$ & $\begin{array}{l}\text {-Enhance } \\
\text { the } \\
\text { professionalism } \\
\text { of the } \\
\text { construction } \\
\text { industry } \\
\text {-Enhance } \\
\text { the procure } \\
\text { to pay } \\
\text { strategy } \\
\text {-Raise the } \\
\text { sophistication } \\
\text { level of } \\
\text { the } \\
\text { construction } \\
\text { industry }\end{array}$ & $\begin{array}{l}\text {-Foster a } \\
\text { quality and } \\
\text { environmental } \\
\text { friendly } \\
\text { culture } \\
\text {-Enhance } \\
\text { occupational } \\
\text { safety and } \\
\text { health } \\
\text {-Adopt MS on } \\
\text { the } \\
\text { manufacture } \\
\text { or import } \\
\text { construction } \\
\text { building } \\
\text { materials }\end{array}$ & $\begin{array}{l}\text {-Promote } \\
\text { and enforce } \\
\text { the use of } \\
\text { skilled } \\
\text { labour } \\
\text { (building } \\
\text { capability) } \\
\text {-Nurture the } \\
\text { desire to } \\
\text { work in the } \\
\text { construction } \\
\text { industry } \\
\text { amongst the } \\
\text { local } \\
\text { workforce } \\
\text { (building } \\
\text { capacity) }\end{array}$ & $\begin{array}{l}\text {-Continuously } \\
\text { innovates } \\
\text { construction } \\
\text { processes and } \\
\text { techniques } \\
\text {-Stimulate } \\
\text { R\&D activities } \\
\text { through } \\
\text { resource } \\
\text { pooling } \\
\text { initiative } \\
\text { amongst key } \\
\text { players and } \\
\text { provision of } \\
\text { R\&D } \\
\text { infrastructure }\end{array}$ & $\begin{array}{l}\text {-Encourage } \\
\text { knowledge } \\
\text { sharing for } \\
\text { continuous } \\
\text { inprovement } \\
\text {-Develop } \\
\text { local } \\
\text { construction } \\
\text { software } \\
\text { industry }\end{array}$ & $\begin{array}{l}\text {-Ensure } \\
\text { industry } \\
\text { sustainability } \\
\text { in the } \\
\text { liberalised } \\
\text { environment } \\
\text {-Market the CI } \\
\text { in a focused } \\
\text { global manner } \\
\text {-Enhance } \\
\text { industry's } \\
\text { access to } \\
\text { financing } \\
\text {-Develop } \\
\text { complimentary } \\
\text { industries }\end{array}$ \\
\hline
\end{tabular}

Figure 2: Construction Industry Master Plan (CIMP) 2006-2015

(Source:(CIMP, 2007)) 


\subsection{Construction Industry Master Plan (CIMP) 2006-2015}

The CIMP 2006-2015 published in December 2006 as a way to represent the future direction of the Malaysian construction industry. Modular construction is in line with Strategic Thrust 3: Towards highest standard of quality, occupational safety and health and environmental practices: and Strategic Thrust 5: Innovate through RandD to adopt a new construction method (CIMP, 2007). The envisioned of CIMP 2006-2015 is to be progressive construction sector that lies on sustainable and innovative development. Figure.2 shows the overall strategic thrusts in CIMP and its enabling recommendations

\subsection{Industrialised Building System (IBS) in Malaysia}

Table 1: Categorisation of IBS in Malaysia

\begin{tabular}{|c|c|c|}
\hline IBS Introduce in & & IBS Component \\
\hline \multirow{3}{*}{ Early 60 's } & 1. & Frame System \\
\hline & 2. & Panel System \\
\hline & 1. & Precast concrete framing, panel and box systems \\
\hline \multirow{2}{*}{ Early 90's } & 2. & Load bearing block \\
\hline & 3. & Sandwich panel \\
\hline \multirow{3}{*}{2003} & 1. & Pre-cast concrete framing, panel and box systems \\
\hline & 2. & Formwork systems \\
\hline & 3. & Steel framing systems \\
\hline \multirow{4}{*}{2010} & 1. & Pre-cast concrete systems \\
\hline & 2. & Formwork systems \\
\hline & 3. & Steel framing systems \\
\hline & 4. & Prefabricated timber framing systems \\
\hline
\end{tabular}

(Source:(Muhamad Faiz Musa, Mohammad, Mahbub, \& Yusof, 2014))

Industrialised Building System (IBS) is a term used by the Malaysian construction industry and government to claim the use of prefabrication of components in building construction and the adoption of building industrialisation. IBS is a construction technique in which the components are manufactured in a controlled environment (on or off-site), transported, positioned and assembled into a structure with minimal additional site work (Kamar, 2012; Mohammad, 2013). Malaysia has categorises IBS to suit the local practice through the years 
as shown in Table 1. Malaysia is still in the stage of hybridization system and in the initial phase to implement modular building. Modular construction is not a part of the current CIDB categorisation of IBS components.

The new IBS Roadmap 2011-2015 objectives are quality, efficiency, competency and sustainability. A sustainable IBS industry will contribute to the competitiveness of Malaysian construction industry. The first objective of the roadmap is excellent quality designs with highquality components, and buildings are the desired outcome of IBS. Aesthetics should be promoted through innovation. The second objective is to ensure the usage of IBS; the completion time speeds up for an IBS project or building, more predictable and efficiently manage. Third, to have a ready supply of competent IBS professionals and workers throughout the entire project lifecycle: from design, manufacture and building to maintenance. The last objective is to create a financially sustainable IBS industry that balances user affordability and manufacturer viability (CIDB, 2010).

\subsection{Modular Construction}

Modular construction was introduced back in the 1940s. Since then, modular construction has been improving and had revolutionised through the years. Modular construction is an innovative process of building construction using a concept of mass production of industrialised systems (identical and modules). The modules are produced at the factory within controlled environments that includes the logistic and assembly aspect of it on the site. It is done in proper coordination with thorough planning (MBI, 2008).

Structurally, modular buildings are stronger than traditional construction because each modular unit is engineered to withstand loads independently, the rigors of transportation at the same time and the lifting onto the foundations. Once together and sealed, the modular units become one integrated wall, floor and roof. Offsite construction ensures better construction quality management. Materials deliver to the plant location and securely store in the manufacturer's warehouse prevent damage or deterioration from moisture. Manufacturing facilities have quality assessment and control (QA/QC) programs with independent inspection (MBI, 2010; Muhamad Faiz Musa et al., 2014).

Modular construction removes approximately $80 \%$ of the building construction activity from the site reduce disruption, vehicular traffic and improves overall safety and security. For schools, hospitals, or other active businesses and public buildings, modular construction reduces on-site activity. It is a tremendous advantage and thereby eliminating a large part of the on-going construction hazards. As clients, building owners and designers look for more sustainable designs to reduce environmental impact, modular construction is inherently natural fit. Modular units are produced in a controlled environment that reduces waste through avoidance upstream rather than diversion downstream. Along with improved quality management and control throughout the construction process and significantly less on-site activity and disturbance, modular construction inherently promotes sustainability. In addition, modular construction produces less noise and improves air quality because the modular structure is substantially completed in a factory-controlled environment using dry materials (Lawson, 2012). 
Modular construction takes most of the production away from the construction site. Faster and efficient factory processes are replacing the slow, unproductive site activities. Production of modular units occurs simultaneously with site work, allowing projects to be completed faster compare to conventional construction method. In addition, modular units used for modular construction is 'smart', whereby each modular unit is identical, produce using the same materials, same building standards and architectural specifications for traditional construction. Once assemble, the modular units are virtually indistinguishable from their sitebuilt counterparts. Modular construction is also movable and flexible where it can be dismantle, refurbish and move to another location for new use. Thus, reduces the need for raw materials and minimising the amount of energy to create a building to meet the new need (MBI, 2013).

\subsection{Methodology}

This paper is part of an on-going research on adopting modular construction through IBS approach in the Malaysian construction industry. It is still at the initial stage as such the information presented is primarily on the review of relevant literature on the modular construction, IBS and the Malaysian construction industry. The nature of this research is to introduce modular construction that is in line with the current state of Malaysian construction industry and Malaysian government initiatives. The information gathered is from the secondary data comprising relevant books, journals, reports, conference proceedings and web page.

\subsection{Results and Discussions}

Findings from the literature illustrate the relationship between offsite construction (modular construction and IBS) with sustainability. Modular construction and IBS contribute to achieving sustainability in the construction industry, overall life cycle of a building and towards the environment. Modular construction contributes to sustainability by producing less waste (offsite and on-site), high quality products and reducing damage towards the environment and ecosystems. Modular construction produces less air and sound pollution, safety on-site and in the factory vastly improve, flexible, recycle and reduce site disruption. Modular construction provides sustainable design and construction solutions for improved environmental impact. In addition, modular construction can be categorised as sustainable construction, MMC and offsite construction.

The introduction of modular construction through IBS approach is in line with the Malaysian government's ambitious move to transform the country's construction industry to a higher level. Based on a review of CIMP 2006-2015, modular construction is in line with Strategic Thrust No.3: Towards highest standard of quality, occupational safety and health and environmental practices; and Strategic Thrust No.5: Innovate through R\&D to adopt a new construction method. From the findings, modular construction contributes to sustainability, produces high-quality product and increase safety off-site and on-site. These 
benefits are in line with CIMP's Strategic Thrust No.3. In addition, modular construction is new and an innovation in the Malaysian construction industry which is very much in line with CIMP's Strategic Thrust No.5.

CIDB current categorisation of IBS components does not include modular construction. However, there has been a move to introduce modular construction or modular house in the categorisation in the near future. The introduction of modular construction through the IBS approach seems quite timely and appropriate with the current government's agenda. Based on a review of the new IBS Roadmap 2011-2015, modular construction can achieve all four objectives of the roadmap that are quality, efficiency, competency and sustainability. The production of modular construction is conducted in a factory, in a controlled environment which makes it easier for modular construction to achieve all four objectives of the IBS roadmap.

Construction research that focuses on modular construction is at an initial stage and relatively a new field, mainly in developing countries such as Malaysia. Modular construction has been used, practiced and implemented in developed countries such as the US, Japan and UK for many years. These was due to its benefits and advantages to the construction industry players and stakeholders, building owners and end users in the respective countries. Modular construction had been used by the US and UK since World War II in order to solve the residential problems for their soldiers in the war. Furthermore, after World War II, the high demand for housing and building were the primary reasons for using industrial methods in the construction industry based on economic goals, quick, cheap and mass building production. More research on modular construction needs to be conducted in the context of the Malaysian construction industry scenario. It is necessary to enable Malaysia to move forward from the conventional prefabrication of the IBS towards modular construction or building, which will revolutionise the pattern and mode of the offsite construction industry.

Among the challenges in adopting modular construction in the Malaysian construction industry will be the issues of readiness, awareness and acceptance of Malaysian construction stakeholders, players, building owners, and end users towards modular construction and building. Even though modular construction has proven to be beneficial and provided positive impacts, there will nonetheless be challenges to the adoption and implementation of modular construction. Modular construction provides high construction quality and productivity, reducing risks related to occupational safety and health. Furthermore modular construction alleviatite issues for skilled workers and dependency on foreign labour, and achieving the ultimate goal of reducing the overall cost of construction. If these benefits are to be returned, it will be transfered directly to the owners or occupiers in the form of better building quality, reducing the purchasing cost, in the long run will increase the value of the property which will eventually improve and enhance the quality of life of the owners or occupiers. Modular construction contributes to the sustainability agenda by producing less waste, high quality products, reduces damage towards the environment, less air and sound pollution, safety onsite and in the factory while vastly improve and reduce site disruption. 


\subsection{Conclusion}

The current study has established the importance of modular construction towards enhancing the Malaysian construction industry. There is a need for the Malaysian construction industry to opt for a new and improved construction technique, in order to shift from the traditional construction to the modern method of construction and sustainable construction approach. The literature presented has shown that the current states and issues of Malaysian construction industry and the Malaysian government initiatives in modernising and achieving sustainability in the construction industry. Thus the introduction of modular construction is in line and suit the Malaysian government ambition. From the literature review, there are many advantages and benefits that can be capitalised from the adoption of the modular construction. In the end, the outstanding quality and durability of buildings delivered to the owner or occupier and end users will lead them to a better quality of living and, therefore, to a better quality of life. Future studies to examine the overall process, requirements and the implementation of the system including getting critical feedbacks from players and potential end users. The results of the main research will, hopefully, provide the basis for a guideline to support and enhance the Malaysian construction industry's move into a positive transformation aimed in the near future.

\section{Acknowledgement}

The Authors wish to thank and acknowledge the contributions of Construction Industry Development Board (CIDB) and Universiti Teknologi MARA.

\section{References}

CIDB. (2003). IBS roadmap 2003-2010. Kuala Lumpur.

CIDB. (2010). IBS Roadmap 2011-2015. Kuala Lumpur: Construction Industry Development Board

CIMP. (2007). Construction Industry Master Plan 2006-2015 (CIMP 2006- 2015). Kuala Lumpur: Construction Industry Development Board CIDB.

Hamid, Z. A., Kamar, K.A.M., Zain, M.Z.M., Ghani, M.K., Rahim,A.H.A. (2008). Industrialised Building System (IBS) in Malaysia: The Current State and R and D Initiatives Malaysian Construction Research Journal (MCRJ), 2(1), 111.

Kamar, K. A. M., Hamis, Z.A., Dzulkalnine, N. (2012). Industrialised Building System (IBS) Construction: Measuring the Perception of Contractors in Malaysia.

Lawson, R. M., Ogden, Ray G., Bergin, Rory. (2012). Application of Modular Construction in High-Rise Buildings. Journal of architectural engineering, 18(2), 148-154. doi: 10.1061/(asce)ae.1943-5568.0000057

MBI. (2008). Commercial Modular Construction Report (pp. 1-23).

MBI. (2010). Improving Construction Efficiency and Productivity with Modular Construction. 
Musa, M.F., et.al. / Asian Journal of Environment-Behaviour Studies (ajE-Bs), 3(10) Sep / Oct 2018 (p1-9)

MBI. (2013). Why Build Modular? Retrieved 10/10, 2013, from http://www.modular.org/HtmIPage.aspx?name=why modular

Mohammad, M. F. (2013). Construction Environment: Adopting IBS Construction Approach towards Achieving Sustainable Development. Paper presented at the AcE-Bs 2013 Hanoi, Hanoi Architectural University, Hanoi, Vietnam.

Musa, M. F., Mohammad, M. F., Mahbub, R., \& Yusof, M. R. (2014). Enhancing the Quality of Life by Adopting Sustainable Modular Industrialised Building System (IBS) in the Malaysian Construction Industry. Procedia - Social and Behavioral Sciences, 153, 79-89. doi: 10.1016/j.sbspro.2014.10.043

Musa, M. F., Yusof, M. R., Mohammad, M. F., \& Mahbub, R. (2014). Characteristics of Modular Construction: Meeting the Needs of Sustainability and Innovation. Paper presented at the Colloqium on Humanities, Science and Engineering (CHUSER 2014), Penang. 